\title{
Field Evaluation of New Fungicide, Victory 72 WP for Management of Potato and Tomato Late Blight (Phytophthora infestans (Mont) de Bary) in West Shewa Highland, Oromia, Ethiopia
}

\author{
Mohammed Amin*, Negeri Mulugeta and Thangavel Selvaraj \\ Department of Plant Science and Horticulture, College of Agriculture and Veterinary Science, Ambo University, Post Box No: 19, Ethiopia
}

\begin{abstract}
The field experiment was carried out to evaluate the management of tomato (Roma-VF) and potato (Guddeni) late blight using a new fungicide, Victory 72 WP and Ridomil gold to select the more effective dosage of the new fungicide option against potato and tomato late blight under field conditions at Toke Kutaye district of West Shoa, Ethiopia, during the main cropping season in 2012. The experiment was arranged in randomized complete block design with three replications. Two types of fungicide applications (Ridomil gold and Victory 72 WP) in weekly intervals were established and unsprayed plot was used as a control. Late blight infection was prevalent in the experimental year, and a significant amount of disease was detected $(P<0.05)$. Application of fungicide treatments considerably reduced late blight progress, with a corresponding increase in tuber and fruit yields of potato and tomato, respectively. Significant differences were observed among treatments in potato and tomato plants in terms of disease severity (DS), area under disease progressive curve (AUDPC), disease progressive rate (r). Among the different treatments, Victory 72 WP fungicide treated potato and tomato plants recorded the lowest DS, AUDPC, disease progressive rate. Based on late blight disease occurrence, application of Victory 72 WP fungicide significantly reduced disease development and increased tuber and fruit yield in both potato and tomato crops, respectively as compared to the Ridomil gold fungicide applications. This is an indication of the reliability and promise as well as the exhibition of great potential of the Victory $72 \mathrm{WP}$ is the effective control of the late blight of potato and tomato in Toke Kutaye district of West Shoa, Ethiopia.
\end{abstract}

Keywords: Fungicides; Late blight; Potato; Ridomil gold; Tomato; Victory $72 \mathrm{WP}$

\section{Introduction}

Like many other countries in the world, potato (Solanum tuberosum L.) and tomato (Lycopersicon esculentum Mill.) crops are very important food and cash crops especially on the highland and mid altitude areas of Ethiopia [1]. Ethiopia's potato area had grown to 160,000 ha, with average yields around 9 tons/ha. About 152,956,115 million tons of tomatoes were produced in the world in 2011, and with a yield potential of up to 48.1 tons/ha [2]. In Ethiopia, the total area under production reaches 51,698 hectares and annual production is estimated to be more than 230,000 tons [3]. The national average of tomato fruit yield in Ethiopia is very low ( 7 tons/ha) compared even to the neighboring African countries like Kenya (16.4 tons/ha) and less than $50 \%$ of the current world average yield of 27 tons/ha [3]. Current productivity under farmers' condition in Ethiopia is 9 tons/ha whereas yield up to 40 tons/ha recorded on research plots [4].

Farmers get lower yield mainly due to diseases, pests and suboptimal fertilization. The most important factors responsible for the low productivity of potato and tomato are diseases and insect pests. Among those diseases, early and late blight fungal diseases of solanaceous vegetables are the most destructive and widespread in tropical, subtropical and temperate regions of the world [5]. Late blight caused by Phytophthora infestans (Mont) de Bary is one of the most significant constraints to potato and tomato productions up to $90 \%$ of crop losses in cool and wet weather conditions in the country [6]. Yield losses due to the disease are attributed to both premature death of foliage and diseased tubers in potato and foliage, stems and fruits of tomato. The disease is more severe in humid and high rainfall areas and it occurs at a low intensity in dry areas [7]. It causes serious loss in yield and quality as well as reduces its marketability values [8]. Nonetheless, loss due to the disease was estimated to range between $65-70 \%$ and complete crop failures are frequently reported [9].

The management of potato and tomato crops against this pathogen is important to maximize the crops' yield. The disease occurs throughout the major potato and tomato production areas and it is difficult to produce both the crops during the main rainy season without chemical protection measures $[1,5,10,11]$. Fungicides are among the most efficient control options available to the growers in Ethiopia. This is particularly important in developing countries such as Ethiopia, where the setup of efficient control programs for potatoes and tomatoes are inadequate. The newly introduced fungicide could be treated against late blight of potato and tomato cultivars, which could reduce the need of application of high fungicide, decrease the risk to human health, environmental contamination and increase the economic benefit of farmers. Therefore, the present verification test research work was carried out to evaluate the management of potato (Local var.) and tomato (Roma-VF) against late blight using a new fungicide, Victory $72 \mathrm{WP}$ and Ridomil gold to select the more effective dosage of the new fungicide option against the potato late blight.

*Corresponding author: Mohammed Amin, Department of Plant Science and Horticulture, College of Agriculture and Veterinary Science, Ambo University, Post Box No: 19, Ethiopia, E-mail: aminmahammed@gmail.com

Received July 23, 2013; Accepted August 12, 2013; Published August 19, 2013

Citation: Amin M, Mulugeta N, Selvaraj T (2013) Field Evaluation of New Fungicide, Victory 72 WP for Management of Potato and Tomato Late Blight (Phytophthora infestans (Mont) de Bary) in West Shewa Highland, Oromia, Ethiopia. J Plant Pathol Microb 4: 192 doi:10.4172/2157-7471.1000192

Copyright: (c) 2013 Amin M, et al. This is an open-access article distributed under the terms of the Creative Commons Attribution License, which permits unrestricted use, distribution, and reproduction in any medium, provided the original author and source are credited. 
Citation: Amin M, Mulugeta N, Selvaraj T (2013) Field Evaluation of New Fungicide, Victory 72 WP for Management of Potato and Tomato Late Blight (Phytophthora infestans (Mont) de Bary) in West Shewa Highland, Oromia, Ethiopia. J Plant Pathol Microb 4: 192 doi:10.4172/21577471.1000192

Page 2 of 4

\section{Materials and Methods}

\section{Description of the study area}

Experimental trail was conducted in previous potato and tomato cultivated fields at Guder of Toke Kutaye district, West Showa, Oromia, Ethiopia during the main cropping season on 2012. The altitude of the study areas was between 1900 and $3100 \mathrm{~m}$. a. s. l, geographical positions of $\mathrm{N} 08^{\circ} 43.423-\mathrm{N} 10^{\circ} 12.082$ and $\mathrm{E} 037^{\circ} 28.902-040^{\circ} 62.590$. Heavy rain observed from onset of July to the end of August. The annual rainfall ranges from $1000-1588.06 \mathrm{~mm}$ and the temperature of the district ranged between $9.44^{\circ} \mathrm{C}$ and $21.86^{\circ} \mathrm{C}$ with average of $15.65^{\circ} \mathrm{C}$. The soil of the experimental site is light red in color, clay loam in texture and $\mathrm{pH}$ value of 6.8. The late blight pressure is generally high in Guder location during the rainy season.

\section{Materials used}

A seed of improved susceptible tomato variety (Roma-VF) was used and obtained from Melkasa Agricultural Research Center, Ethiopia. Seed of improved potato variety (Local) was obtained from Holleta Agricultural Research Center, Ethiopia. Two fungicides, Victory $72 \mathrm{WP}$ with active ingredient of Mancozeb $640 \mathrm{~g} / \mathrm{kg}+$ Metalaxyl $80 \mathrm{~g} / \mathrm{kg}$ and Ridomil gold with active ingredient of Metalaxyl $40 \mathrm{~g} / \mathrm{kg}+$ Mancozeb $640 \mathrm{~g} / \mathrm{kg}$ ) were obtained from Axum Greenline Trading Private Limited Company, Ethiopia.

\section{Experimental design and treatments}

The experiments were arranged in randomized complete block design with three replications. Three fungicide treatments (Victory 72 WP, Ridomil gold and no treatment) were used. In this experiment, Ridomil gold was used as a standard check. Likewise, Victory $72 \mathrm{WP}$ was a new fungicide chemical which have not been used before for the controls of late blight disease in Ethiopia. Seedlings of improved potato local variety (Guddeni) which is moderately susceptible to late blight were planted into each plot size of $4.8 \times 3.2 \mathrm{~m}$. Spacing between plants and rows were maintained as $40 \mathrm{~cm}$ and $80 \mathrm{~cm}$, respectively. There were 8 plants per row and the four central rows were harvested for determining tuber yield. Also, a seed of tomato variety, Roma-VF was shown on a standard seed bed with a size of $1.8 \times 2.4 \mathrm{~m}$. Apparently healthy seeds were sown into the experimental field with each plot sizes of $3.6 \times 2.7 \mathrm{~m}$, and distance between rows and between plants were 45 and $60 \mathrm{~cm}$, respectively. There were 6 plants per row and the four central rows were harvested for determining fruit yield. Each potato and tomato plots consisted of a total six rows. Each plot and blocks were separated by a buffer zone of 1.5 and $2.0 \mathrm{~m}$, respectively to prevent fungicide drift or cross contamination both for potato and tomato field trials. First spray of fungicides was started soon after the initial appearance of disease symptoms using knap-sack sprayer. The fungicides were applied at the rate of $2.5 \mathrm{~kg} / \mathrm{ha}$ at an interval of seven days. All agronomic practices such as weeding, cultivation were kept uniform for all treatments in each plot.

\section{Disease assessment}

Incidence and severity: Natural inoculation was relied upon in all experimental plots. Disease incidence and severity were assessed on the central two rows every week. Incidence of late blight was assessed by counting the number of plants on the middle four rows and were expressed as percentage of total plants. Five plants were selected randomly from each replicate per treatment, and then five leaves of each plant were used to determine the disease severity [12].

The per cent incidence was calculated as:

$$
\text { Disease Incidence }=\frac{\text { Nunmer of diseased plant }}{\text { Total number of plant inspected }} \times 100
$$

Severity of late blight was recorded on the basis of 1-6 rating scales as described by Gwary and Nahunnaro [13]. where scale $1=$ trace to $20 \%$ leaf infection, $2=21-40 \%$ leaf infection, $3=41-60 \%$ infection, $4=61-80$ infection, $5=81-99 \%$ infection, $6=100 \%$ leaf infection or the entire plant defoliation and then the rating scales were converted into percentage severity index (PSI) for the analysis of disease severity using the following formula:

$$
\text { Percentage Severity Index }=\frac{\text { Sumof Individual numerical rating }}{\text { Total Number of assessed } \times \text { Maximum score in scale }} \times 100
$$

\section{Disease progression analysis}

Area under the disease progress curve (AUDPC) and growth curve models were developed for the disease progress data. AUDPC values were calculated for each plot using the following equation [14].

$$
\text { AUDPC }=\sum_{i=1}^{n-1} 0.5\left(x_{i+1}+x_{i}\right)\left(t_{i+1}-t_{i}\right)
$$

Where, $\mathrm{X}_{\mathrm{i}}$ is the cumulative disease severity expressed as a proportion at the $i^{\text {th }}$ observation, $t_{i}$ is the time (days after planting) at the $\mathrm{i}^{\text {th }}$ observation and $\mathrm{n}$ is total number of observations. AUDPC values were then used in analysis of variance to compare amount of disease among plots with different treatments. Logistic, in $[(\mathrm{Y} / 1-\mathrm{Y})]$ and Gompertz, -in [-in(Y)] [15]. Models were compared for estimation of disease progression parameters from each treatment. The goodness of fit of the models was tested based on the magnitude of the coefficient of determination $\left(\mathrm{R}^{2}\right)$. The appropriate model was used to determine the apparent rate of disease increase (r) and the intercept of the curve.

\section{Assessment of yield data}

Data related to yields were recorded from the central four rows on each plot for each treatment. Tubers and fruits were considered ready for picking, when $50 \%$ of tomato fruits turned yellow or red. Mean yield of tubers and fruits were assessed on each plot of four central rows.

\section{Data analysis}

Data on disease parameters (disease incidence, disease severity, PSI, AUDPC and disease progression rate (r), yield were subjected to analysis of variance (ANOVA) using Statistical Analysis System (SAS) version 9.1 software. Fisher's protected Least Significant Difference (LSD) values were used to separate differences among treatment means $(\mathrm{P}<0.05)$ for the field evaluation of potato and tomato late blight disease.

\section{Results}

\section{Disease incidence in tomato and potato}

Data on the disease incidence revealed that no significant differences among treatments in their initial and final percent disease incidence. During the first disease assessment (53 DAP), treatments did not show uniform initial disease incidence. Minimum initial percent disease incidence was observed in Ridomil gold and Victory $72 \mathrm{WP}$ treated potato plants with the mean values of 18 and $20.0 \%$ and in tomato plants with the mean values of 20 and $20 \%$, respectively. At the end of disease assessment (113 DAP), all the experimental plots had recorded $100 \%$ disease incidence. 
Citation: Amin M, Mulugeta N, Selvaraj T (2013) Field Evaluation of New Fungicide, Victory 72 WP for Management of Potato and Tomato Late Blight (Phytophthora infestans (Mont) de Bary) in West Shewa Highland, Oromia, Ethiopia. J Plant Pathol Microb 4: 192 doi:10.4172/21577471.1000192

\section{Disease severity in tomato and potato}

Among the experimental treatments, percent final disease severity was highly significant $(\mathrm{P}<0.05)$. All the treatments showed different level of reaction to late blight of tomato compared to untreated control. The least percent disease severity was recorded in Victory $72 \mathrm{WP}$ and Ridomil gold treatments with mean values of 15.67 and $18.90 \%$ in tomato treated plants, respectively. Therefore, in comparisons, the highest percent final disease severity $(67.7 \%)$ was recorded from untreated plots. Likewise in potato field, the least percent disease severity was recorded in Victory $72 \mathrm{WP}$ treatments with mean values of $40.74 \%$ in study area. Similarly in Ridomil gold treatments, the percent severity was recorded $40.74 \%$ in Guder field trial of potato, Therefore, in comparisons, the highest percent final disease severities $(69.72 \%)$ was recorded from untreated control plots (Table 1).

\section{Area under disease progressive curve (AUDPC) in tomato and potato field trail}

AUDPC values on tomato and potato late blight exhibited significant differences $(\mathrm{P}<0.05)$ within treatments. The minimum AUDPC 711.7\%day was observed on Victory 72 WP treated tomato plots followed by Ridomil gold (894.6\%-days) and the maximum AUDPC values were recorded from control with a value of $1923.4 \%$-day. In the same way, the lowest AUDPC 743.7\%-day was observed on Victory 72 WP treated potato plots followed by Ridomil gold (842.6\%-days) and the maximum AUDPC values were recorded from control with a value of $1973.4 \%$-day (Table 1).

\section{Disease progressive rate $(r)$ of tomato and potato late blight}

Disease progressive rates were significantly different at $(\mathrm{P}<0.05)$ as compared with the standard control (Tables 2 and 3). In treatments, the acceptable regression equation with coefficient of determination $\left(\mathrm{R}^{2}\right)$ ranging from 0.43 to 0.68 in tomato fields and 0.25 to 0.62 in potato

\begin{tabular}{|l|c|c|c|c|}
\hline Treatments & \multicolumn{2}{|c|}{ Tomato field } & \multicolumn{2}{c|}{ Potato field } \\
\hline & Severity (\%) & $\begin{array}{c}\text { AUDPC } \\
\text { (\%-days) }\end{array}$ & Severity (\%) & $\begin{array}{c}\text { AUDPC } \\
\text { (\%-days) }\end{array}$ \\
\hline Victory 72 WP & $15.67^{\mathrm{c}}$ & $711.70^{\mathrm{c}}$ & $40.74^{\mathrm{b}}$ & $743.70^{\mathrm{c}}$ \\
\hline Ridomil gold & $18.90^{\mathrm{b}}$ & $894.60^{\mathrm{b}}$ & $40.74^{\mathrm{b}}$ & $842.60^{\mathrm{b}}$ \\
\hline $\begin{array}{l}\text { Untreated } \\
\text { control }\end{array}$ & $67.70^{\mathrm{a}}$ & $1923.40^{\mathrm{a}}$ & $69.72^{\mathrm{a}}$ & $1973.40^{\mathrm{a}}$ \\
\hline Mean & 34.09 & 1176.57 & 50.4 & 1186.57 \\
\hline CV (\%) & 15.26 & 10.79 & 14.26 & 12.79 \\
\hline LSD (5\%) & 20.26 & 452.2 & 18.26 & 432.2 \\
\hline
\end{tabular}

Means followed by the same letter in each column are not significantly differen using Least Significant Difference $(p=0.05), C V=$ Coefficient of variation, $L S D=l e a s t$ significant difference, $A U D P C=a r e a$ under disease progress curve. Means in column followed by the same letter(s) are not significantly different.

Table 1: Effect of fungicide treatments on late blight of tomato and potato with disease severity percentage and mean AUDPC in field trail.

\begin{tabular}{|l|l|l|l|l|l|}
\hline Treatments & Intercept & $\begin{array}{l}\text { Disease progressive } \\
\text { Rate }(\mathbf{r})\end{array}$ & $\mathbf{R}^{\mathbf{2}}$ & SEE & $\begin{array}{l}\text { Significance } \\
\mathbf{( P < 0 . 0 5 )}\end{array}$ \\
\hline Victory72WP & 0.65 & 0.43 & 0.368 & 0.0001 \\
\hline Ridomil-gold & 0.68 & 0.47 & 0.297 & 0.0001 \\
\hline Untreated control & 0.83 & 0.68 & 0.476 & 0.0001 \\
\hline
\end{tabular}

SEE: Standard Error of Estimate

The highest disease progressive rate was observed from untreated plot tomato and potato with values of 0.83 and 0.79 , respectively which is exceeds Victory 72 WP by 0.29 units per day. Although, disease progressive rate of late blight increased more rapidly in untreated control compared to other treatments.

Table 2: Disease progressive rate ( $r$ ) of tomato late blight severity on various treatments.

\begin{tabular}{|l|l|l|l|l|l|}
\hline Treatment & Intercept & $\begin{array}{l}\text { Disease progressive } \\
\text { Rate } \mathbf{( r )}\end{array}$ & R2 & SEE & $\begin{array}{l}\text { Significance } \\
(\mathbf{P}<\mathbf{0 . 0 5})\end{array}$ \\
\hline Victory72WP & 0.50 & 0.25 & 0.383 & 0.0001 \\
\hline Ridomil-gold & 0.63 & 0.40 & 0.234 & 0.0001 \\
\hline Untreated control & 0.79 & 0.62 & 0.456 & 0.0001 \\
\hline
\end{tabular}

$\mathrm{SSE}=$ Standard Error Estimate

Table 3: Disease progressive rate ( $r$ ) of potato late blight severity on three different treatments from August to November at Guder during 2012 main growing season.

\begin{tabular}{|l|c|c|c|c|}
\hline Treatment & \multicolumn{2}{|c|}{ Tomato field } & \multicolumn{2}{c|}{ Potato field } \\
\hline & $\begin{array}{c}\text { Mean fruits } \\
\text { yield yield } \\
\text { (tons/ha) }\end{array}$ & $\begin{array}{c}\text { Yield loss } \\
\text { (\%) }\end{array}$ & $\begin{array}{c}\text { Mean tuber } \\
\text { yield yield } \\
\text { (tons/ha) }\end{array}$ & $\begin{array}{c}\text { Yield loss } \\
\text { (\%) }\end{array}$ \\
\hline Victory 72 WP & 21.1 & 0 & 65.21 & 0 \\
\hline Ridomil gold & 18.5 & 12.35 & 63.08 & 3.27 \\
\hline Untreated control & 4.3 & 79.81 & 47.67 & 26.89 \\
\hline
\end{tabular}

Table 4: Mean yield and yield loss estimation due to late blight of tomato and potato under various treatments at study area during 2012 main growing season.

treated fields were produced with the linearized form of final late blight severity regressed over time in days after planting. Disease progressive rate in the untreated plot was increased at the rate of 0.83 units per day which was higher than the best performed treatment so called Victory 72 WP.

\section{Mean yield of tomato fruit and potato tuber}

There were significant differences $(\mathrm{P}<0.05)$ within treatments on fruit and tuber yield at study location. All treatments were exceeds the untreated plots. The maximum mean fruit yield (21.1tons/ha) was recorded from the Victory 72WP followed by Ridomil gold (18.5 tons/ ha). While, the minimum fruit yield was recorded from control (4.3 tons/ha). Moreover, the highest mean tuber yield was harvested from plots treated with Victory 72WP followed by Ridomil gold with mean values of 65.21 and 63.08 tons/ha (Table 4).

\section{Yield loss estimation}

The variation in tuber and fruit yield losses was observed among different treatments. In comparison, in untreated control plots, tuber and fruit yield losses was notably higher than protected plots. Yield losses were significantly reduced by fungicide chemical compared to other experimental treatments. The highest fruit yield loss was recorded from untreated plots $(79.81 \%)$ compared to the most protected plots (Victory $72 \mathrm{WP}$ ) with a value of $(12.35 \%)$ at spray frequency of weekly interval (Table 4). Similarly, the maximum tuber loss was observed from control plots.

\section{Discussion}

Previously, the fungicides were screened for the control of late blight of tomato and potato in the Central Rift Valley area of Ethiopia. Potential fungicides were also verified on farmers' fields around Melkassa, Ziway and Wondo Genet. Three fungicides (Metalaxyl-M4\%+Mancozeb 64\% (Ridomil gold 68 WP) 350 g/100 liters, Fungomil 250 g/100 liters, and Mancozeb+Metalaxyl (Mancolaxyl 72\%) 250 g/100 liters) were found effective in controlling the disease on tomato and consequently increased marketable fruit yield by $40-66 \%$ [16]. Moreover, compared to the rest of treatments, all fungicide treatments provided significantly better foliar late blight control, and significantly gave higher total yield. The minimum AUDPC value also observed on Victory 72 WP followed by Ridomil gold and gave 711.7 and $894.6 \%$-days, respectively.

In this study, Victory $72 \mathrm{WP}$ consistently retarded late blight 
Citation: Amin M, Mulugeta N, Selvaraj T (2013) Field Evaluation of New Fungicide, Victory 72 WP for Management of Potato and Tomato Late Blight (Phytophthora infestans (Mont) de Bary) in West Shewa Highland, Oromia, Ethiopia. J Plant Pathol Microb 4: 192 doi:10.4172/21577471.1000192

development and the highest yields were obtained from plots treated with Victory 72 WP followed by Ridomil gold. The study has determined that an application of Victory $72 \mathrm{WP}$ and also Ridomil controls late blight and increases yields markedly. The efficacy of these fungicides can be enhanced by increasing the dosage and frequency of application $[17,18]$. The use of protectant and systemic fungicides for managing late blight has perhaps been the most studied aspect of late blights management in temperate countries [19]. Olanya et al. [19] also reported that, with the exception of optimum or scheduled fungicide applications based on favourable weather conditions; the most economical option for disease management is the use of hostplant resistance. The use of cultivars with durable resistance combined with scheduled applications of Protective fungicides has been reported as useful for managing late blight [20] as well as other diseases [15]. The performance of Ridomil gold in controlling late blight under present investigation has been supported by many researchers throughout the world $[17,18,21,22]$. In tropical Africa, the contact fungicide Dithane M 45 (Mancozeb 80\% WP) and the systemic fungicide Ridomil MZ are widely used to control late blight $[19,23]$. Among the fungicides, Filthane M-45, Secure, Melody Duo, Ridomil gold and Metaril are highly effective to minimize late blight and to increase yield of potato. In the present study, a new fungicide, Victory $72 \mathrm{WP}$ was first used in controlling late blight of potato and tomato in West Shoa of Ethiopia. This is because of an excellent potato and tomato late blight control and also reasonable and acceptable price to be invested in chemical control. This study provides new possible alternatives for the management of late blight to both small and large scale potato and tomato producers of Ethiopia.

\section{Conclusions}

Victory 72 WP fungicide treatments significantly reduced the late blight severity of tomato and potato as compared with Ridomil gold treatment and the untreated control in the tested location. This is an indication of the reliability and promise as well as the exhibition of the great potential of the Victory $72 \mathrm{WP}$ to effective control of the late blight of potato and tomato in West Showa, Ethiopia. Therefore, due to reasonable reduction in disease severity, easy application made Victory 72 WP superior in controlling tomato and potato late blight. Based on the results of the this location test carried out in West Showa, Ethiopia on the effectiveness of the test fungicide, Victory $72 \mathrm{WP}$, and consideration of the wide range of late blight disease in potato and tomato controlled, the use of Victory $72 \mathrm{WP}$ by the farming community (both individually and or private sector) will no doubt improve potato and tomato production in West Showa as well as in similar agro-ecology.

\section{References}

1. Borgal HB, Arend C, Jacobi, Kanyarukis S, Kulazia A, et al. (1980) Production, marketing and consumption of potato in the Ethiopia highlands' (Holleta, Awassa, and Alemaya). Center of Advanced training in agricultural development technology, University of Berlin, Berlin.

2. FAOSTAT (2011) Statistical database of the Food and Agriculture of the United Nations. FAO, Rome, Italy.

3. Central Statistics Agency (CSA) (2010) Agricultural sample survey, 2008/2007 Report on area and production of crops (Private peasant holdings, main season). Statistical Authority, Addis Ababa, Ethiopia.

4. Mutitu EW, Muiru WM, Mukunya DM (2008) Evaluation of antibiotic metabolites from actimnomycete isolates for the control of late blight of tomatoes under greenhouse conditions. Asian Journal of Plant Sciences 7: 284-290.

5. Hijmans RJ, Forbes GA, Walker TS (2000) Estimating the global severity of potato late blight with GIS-linked disease forecast models. Plant Pathol 49: 697-705.
6. Denitsa N, Naidenova M (2005) Screening the antimicrobial activity of actinomycetes strains isolated from Antarctica. J Cult Collections 4: 29-35

7. Srivastava A, Handa AK (2010) Hormonal regulation of tomato fruit development a molecular perspective. Journal of Plant Growth Regulation 24: 67-82.

8. Bekele Kassa, Yaynu Hiskias (1996) Tuber yield loss assessment of potato cultivars with different level of resistance to late blight.pp. 149-152. In: Eshetu Bekele, Abdurrahman Abdullah and Aynekulu Yemane (Eds). Proceedings of the 3rd annual conference of crop protection Society of Ethiopia 18-19 May, Addis Ababa Ethiopia.

9. Kasa B, Woldegiorgis G (2000) Effect of planting date on late blight severity and tuber yield on different potato varieties. Pest Management Journal of Ethiopia 4: 51-63.

10. Mesfin (2009) Review of research on diseases of root and tuber crops in Ethiopia. In: Increasing Crop Production through Improved Plant Protection Vol II (eds.) Abraham Tadesse). Plant Protection Society of Ethiopia, Addis Ababa, Ethiopia 169-230.

11. Abd-El-Khair, Karima HE, Haggag E, GEl- Gamal N (2004) Biological control of wilt disease caused by Fusarium oxysporum in fennel under organic farming system. Phytopathology 34: 56-65.

12. Gwary DM, Nahunnaro H (1998) Epiphytotics of early blight of tomatoes in Northeastern Nigeria. Crop Port 17: 619-624.

13. Campbell CL, Madden LV (1990) Introduction to Plant Disease Epidemiology. John Wiley, New York.

14. Van der Plank JE (1963) Plant Diseases: Epidemics and Control, Academic Press, New York, London.

15. Abraham Tadesse (2009) Increasing Crop Production through Improved Plant Protection, Vol. II, Plant Protection Society of Ethiopia (PPSE), PPSE and EIAR, Addis Ababa, Ethiopia.

16. Islam MR, Dey TK, Rahman MM, Hossain MA, Ali MS (2002) Efficacy of some fungicides in controlling late blight of potato. Bangladesh Journal of Agriculture Research 27: 257-261.

17. Tsakiris E, Karafyllidis DI, Mansfield J, Paraussi G, Voyiatazis D, et al. (2002) Management of potato late blight by fungicides. Proceedings of the Second Balkan Symposium on Vegetables and Potatoes, Thessaloniki, Greece. Acta Horticulture 579: 567-570.

18. Olanya OM, Adipala E, Hakiza JJ, Kedera JC, Ojiambo P, et al. (2001) Epidemiology and population dynamics of Phytophthora infestans in subSaharan Africa: progress and constraints. Africa Crop Science Journal 9: 181 193.

19. Simons MD (1972) Polygenic resistance to plant disease and its use in breeding resistant cultivars. J Environ Qual 1: 232-240.

20. Singh BP, Shekhawat GS (1999) Potato late blight in India. Tech. Bull. No. 27 (revised), India.

21. Singh BP, Singh P, Jhililmil-Gupta H, Lokendra S, Gupta J, et al. (2001) Integrated management of late blight under Shimla hills. National Symposium on Sustainability of Potato Revolution in India, Shimla. Journal of the Indian Potato Association 28: 84-85.

22. Fontem DA (2001) Influence of rate and frequency of Ridomil plus applications on late blight severity and potato yields in Cameroon. Afr Crop Sci J 9: 235-243. 